\title{
PENGUKURAN KINERJA KEUANGAN PT. ULTRA JAYA MILK INDUSTRY TBK. DENGAN PENDEKATAN ECONOMIC VALUE ADDED (EVA)
}

\author{
Sri Wahyuni Nur \\ Fakultas Ekonomi dan Bisnis Islam Institut Agama Islam Negeri (IAIN) Parepare \\ sriwahyuninur20@gmail.com
}

\begin{abstract}
ABSTRAK
Penelitian ini bertujuan untuk mengetahui kinerja keuangan PT. Ultra Jaya Milk Industry Tbk bila di ukur dengan pendekatan Economic Value Added (EVA). Jenis penelitian ini yaitu penelitian kuantitatif dengan pendekatan deskriptif dengan menganalisis data sekunder yaitu laporan keuangan perusahaan Tahun 2017 sampai dengan 2019. Dari hasil analisis data menunjukkan bahwa kinerja keuangan PT. Ultra Jaya Milk Industry Tbk pada tahun 2017 sampai tahun 2019 dalam keadaan baik karena nilai EVA yang diperoleh lebih besar dari nol (EVA>0) sehingga terjadiproses nilai tambah ekonomis (NITAMI) bagi perusahaan, karena laba yang tersedia bias memenuhi harapan stakeholder khususnya Investor.
\end{abstract}

Kata Kunci: Pengukuran Kinerja Keuangan, Economic Value Added (EVA)

\section{PENDAHULUAN}

\section{A. Latar Belakang}

Salah satu tujuan pendirian perusahaan adalah untuk memaksimalkan laba, memaksimunkan nilai saham, dan meningkatkan kesejahteraan pemegang saham. Salah satu tujuan terpenting dalam mengukur kinerja keuangan dilakukan perusahaan adalah untuk menilai apakah tujuan yang ditetapkan perusahaan telah tercapai sehingga kepentingan investor, kreditor, dan pemegang saham dapat dipenuhi. Tercapainya atau tidaknya tujuan ini dapat dilihat sejauh mana kinerja keuangan perusahaan.

Dalam lingkungan bisnis yang kompetitif, penggunaan ukuran kinerja keuangan yang mendasarkan pada analisis rasio keuangan sebagai alat pengukur akuntansi konvensional, seperti rasio profitabilitas memiliki kelemahan utama yaitu mengabaikan adanya biaya modal sehingga sulit untuk menciptakan nilai atau tidak. Untuk mengatasi kelemahan tersebut dikembangkan suatu pendekatan baru dalam mengukur kinerja keuangan suatu perusahaan yaitu Economic Value Added (EVA).

Economic Value Added (EVA) adalah suatu pengukuran dengan memperhatikan secara tepat semua faktor-faktor yang berhubungan dengan penciptaan nilai tambah yang dihasilkan suatu perusahaan dengan cara mengurangi biaya modal yang timbul sebagai akibat dari investasi yang dilakukan. EVA yang positif menandakan perusahaan berhasil menciptakan nilai bagi pemilik modal karena perusahaan mampu menghasilkan tingkat pengembalian yang melebihi tingkat biaya modalnya. Sebaliknya, EVA yang negatif menunjukkan nilai perusahaan menurun karena tingkat pengembalian lebih rendah dari biaya modal.

PT. Ultra Jaya Milk Industry Tbk, adalah perusahaan yang bergerak di bidang makanan dan minuman selalu melakukan perbaikan dan inovasi seiring 


\section{PAY Jurnal Keuangan dan Perbankan. Vol. 2 No. 2, Desember 2020}

dengan perkembangan yang dialami oleh perusahaan. Perusahaan di anggap perlu melakukan analisis kinerja keuangan, hal ini dimaksudkan untuk mengetahui kondisi keuangan perusahaan. Saat ini upaya yang ingin dicapai perusahaan adalah meningkatkan pendapatan dari pengelolaan usaha, dimana dengan adanya peningkatan pendapatan maka akan mempengaruhi profit yang nantinya akan menunjang kontinuitas dari pengelolaan usaha. Salah satu cara yang dilakukan oleh PT. Ultra Jaya Milk Industry Tbk adalah dengan meningkatkan efektivitas pengelolaan manajemen, karena dengan adanya peningkatan efektivitas pengelolaan manajemen perusahaan maka akan mendorong pencapaian tujuan. Pentingnya pengelolaan efektivitas manajemen perusahaan dalam peningkatan kinerja keuangan, maka perlu dilakukan pengukuran kinerja keuangan yang dicapai oleh perusahaan. Hal ini dilakukan untuk mengetahui perkembangan kinerja keuangan yang telah di capai oleh PT. Ultra Jaya Milk Industry Tbk. Untuk mengetahui kinerja keuangan PT. Ultra Jaya Milk Industry Tbk dilakukan dengan metode Economic Value Added (EVA) yang di ukur dengan menggabungkan perolehan nilai dengan biaya yang digunakan untuk memperoleh nilai tambah. Berikut data laba dan modal PT. Ultra Jaya Milk Industry Tbk tahun 2017 sampai 2019.

Tabel 1. Data Perolehan laba Bersih dan Penggunaan Modal Tahun 20172019

\begin{tabular}{|c|c|c|}
\hline Tahun & Laba Bersih & Modal \\
\hline 2017 & $\operatorname{Rp} 584.509 .000 .000$ & $\operatorname{Rp} 4.197 .711 .000 .000$ \\
\hline 2018 & $\operatorname{Rp} 584.200 .000 .000$ & $\operatorname{Rp} 4.774 .956 .000 .000$ \\
\hline 2019 & $\operatorname{Rp} 539.244 .000 .000$ & $\operatorname{Rp} 5.655 .139 .000 .000$ \\
\hline
\end{tabular}

Sumber: Laporan Keuangan Tahunan PT. Ultra Jaya Milk Industry, 2020

Dari perolehan laba bersih dan penggunaan modal pada tabel 1 menunjukkan bahwa laba bersih tahun 2017 sampai tahun 2019 mengalami penurunan, dimana laba bersih tahun 2017 menunjukkan laba bersih lebih besar dari tahun 2018 dan 2019 begitu juga dengan penggunaan modalnya semakin besar pula, namun untuk tahun 2019 sebesar 45\% laba mengalami penurunan tetapi penggunaan modalnya mengalami kenaikan. Oleh sebab itu perlu dilakukan penilaian kinerja keuangan sebagai tolak ukur yang digunakan dalam penelitian ini adalah Economic Value Added (EVA).

Dari hal tersebut, investor yang ingin berinvestasi harus memahami atau melakukan pendekatan terlebih dahulu terhadap perusahaan yang akan menjadi tujuan investasi, salah satunya dengan mempelajari dokumen perusahaan tersebut sebagai gambaran atau acuan dalam pegambilan keputusan untuk berinvetasi.

Berdasarkan uraian diatas, maka peneliti tertarik untuk meneliti Pengukuran Kinerja Keuangan PT. Ultra Jaya Milk Industry Tbk dengan Pendekatan Economic Value Added (EVA).

\section{B. Rumusan Masalah}

Berdasarkan latar belakang yang telah dikemukakan, maka yang menjadi pokok permasalahan adalah "Bagaimanakah Pengukuran Kinerja Keuangan PT. Ultra Jaya Milk Industry Tbk dengan Pendekatan Economic Value Added (EVA)?

\section{Tujuan Penelitian}

Tujuan penelitian ini adalah untuk mengetahui pengukuran kinerja keuangan PT. Ultra Jaya Milk Industry Tbk dengan Pendekatan Economic Value Added (EVA). 


\section{PAY Jurnal Keuangan dan Perbankan. Vol. 2 No. 2, Desember 2020}

\section{TINJAUAN PUSTAKA}

\section{A. Laporan Keuangan}

Menurut Mamduh dan Halim (2012) "Laporan keuangan adalah laporan yang diharapkan bisa memberi informasi mengenai perusahaan, dan digabungkan dengan informasi yang lain, seperti industri, kondisi ekonomi, bisa memberikan gambaran yang lebih baik mengenai prospek dan risiko perusahaan".

Menurut Munawir (2014) laporan keuangan merupakan hasil dari proses akuntansi yang dapat digunakan sebagai alat untuk berkomunikasi antara data keuangan atau aktivitas suatu perusahaan dengan pihak-pihak yang berkepentingan dengan data atau aktivitas perusahaan tersebut.

\section{B. Pengukuran Kinerja Keuangan}

Menurut Fahmi (2011) Kinerja keuangan adalah suatu analisis yang dilakukan untuk melihat sejauh mana suatu perusahaan telah melaksanakan dengan menggunakan aturan-aturan pelaksanaan keuangan secara baik dan benar. Menurut Rudianto (2013) Kinerja Keuangan adalah hasil atau prestasi yang telah dicapai oleh manajemen perusahaan secara efektif selama periode tertentu. Sedangkan menurut Sutrisno (2009) kinerja keuangan perusahaan merupakan prestasi yang dicapai perusahaan dalam suatu periode tertentu yang mencerminkan tingkat kesehatan perusahaan.

\section{Economic Value Added (EVA)}

Economic Value Added (EVA) adalah tolak ukur seberapa jauh perusahaan telah memberikan nilai tambah kepada pemegang saham dalam suatu tahun tertentu. Sehingga, jika para manajer memfokuskan pada EVA, maka para manajer akan konsisten dalam mengelola perusahaan untuk memaksimalkan kekayaan pemegang saham (Kamaluddin, 2011).

Menurut Rudianto (2013:217), Economic Value Added (EVA) merupakan pengukuran kinerja keuangan dengan berdasarkan nilai yang mereflesikan jumlah absolut dari nilai kekayaan pemegang saham dalam operasi perusahaan.

\section{METODE ANALISIS}

Data yang diperlukan dalam penelitian ini diolah dengan menggunakan teknik analisis kuantitatif, yaitu dengan cara melakukan perhitungan dan analisis hasil yang relevan dengan permasalahan. Pengukuran kinerja keuangan ini dilakukan dengan pendekatan Economic Value Added (EVA) dengan langkahlangkah sebagai berikut:

1. Menghitung NOPAT

2. Menghitung Invested Capital

3. Menghitung WACC

4. Menghitung Capital Charges

5. Menghitung Economic Value Added (EVA)

6. Mengukur kinerja keuangan

\section{HASIL PENELITIAN}

A. Laba Bersih dan Neraca PT. Ultra Jaya Milk Industry Tbk

Tabel 2. Laba Bersih PT. Ultra Jaya Milk Industry Tbk Tahun 2017-2019

\begin{tabular}{|c|c|c|c|}
\hline \multirow[b]{2}{*}{ Keterangan } & \multicolumn{3}{|c|}{ Tahun } \\
\hline & $\begin{array}{c}2017 \\
\text { (dalam } \\
\text { jutaan } \\
\text { rupiah) }\end{array}$ & $\begin{array}{c}2018 \\
\text { (dalam } \\
\text { jutaan } \\
\text { rupiah) }\end{array}$ & $\begin{array}{c}2019 \\
\text { (dalam } \\
\text { jutaan } \\
\text { rupiah) }\end{array}$ \\
\hline Penjualan Bersih & 4.879 .559 & 5.472 .882 & 6.241 .419 \\
\hline $\begin{array}{l}\text { Beban Pokok } \\
\text { Penjualan }\end{array}$ & $(3.043 .936)$ & $(3.516 .606)$ & $(3.891 .701)$ \\
\hline Laba Bruto & 1.835 .623 & 1.956 .276 & 2.349 .718 \\
\hline \multicolumn{4}{|l|}{ Beban Usaha } \\
\hline Beban Penjualan & 689.769 & 855.358 & 908.877 \\
\hline $\begin{array}{l}\text { Beban Administrasi } \\
\text { \& Umum }\end{array}$ & 172.082 & 196.900 & 202.883 \\
\hline $\begin{array}{l}\text { Jumlah Beban } \\
\text { Usaha }\end{array}$ & $(861.851)$ & $(1.052 .258)$ & $(1.111 .760)$ \\
\hline LABA USAHA & 973.772 & 904.018 & 1.237 .958 \\
\hline $\begin{array}{l}\text { Penghasilan } \\
\text { (Beban) Lain-lain }\end{array}$ & & & \\
\hline
\end{tabular}


PAY Jurnal Keuangan dan Perbankan. Vol. 2 No. 2, Desember 2020

\begin{tabular}{|l|r|r|r|}
\hline $\begin{array}{l}\text { Laba (Rugi) Kurs } \\
\text { mata uang asing- } \\
\text { bersih }\end{array}$ & 13.886 & 25.851 & 38.358 \\
\hline Penghasilan bunga & 80.355 & 60.084 & 105.655 \\
\hline $\begin{array}{l}\text { Rugi penjualan asset } \\
\text { tetap }\end{array}$ & $(256)$ & $(2.900)$ & $(1.174)$ \\
\hline Penghasilan sewa & 6.701 & 7.423 & 7.019 \\
\hline Beban bunga & $(1.500)$ & $(1.247)$ & $(1.463)$ \\
\hline $\begin{array}{l}\text { Pendapatan bagi } \\
\text { hasil sukuk }\end{array}$ & & & $(0)$ \\
\hline Mudharabah & $(0)$ & & $(0)$ \\
\hline Lain-lain bersih & 3.699 & 13.268 & 85.415 \\
\hline $\begin{array}{l}\text { Penghasilan (beban) } \\
\text { lain-lain bersih }\end{array}$ & $(103.397)$ & $(102.479)$ & $(157.558)$ \\
\hline $\begin{array}{l}\text { LABA SEBELUM } \\
\text { BUNGA DAN } \\
\text { PAJAK }\end{array}$ & $\mathbf{8 7 0 . 3 7 5}$ & $\mathbf{8 0 1 . 5 3 9}$ & $\mathbf{8 4 6 . 2 5 2}$ \\
\hline $\begin{array}{l}\text { BEBAN } \\
\text { (PENGHASILAN) }\end{array}$ & & & \\
PAJAK & & & \\
\hline Pajak kini & 311.454 & 232.101 & 319.260 \\
\hline Pajak tangguhan & $(25.588)$ & $(14.762)$ & $(12.252)$ \\
\hline Beban pajak & 285.866 & 217.339 & 307.008 \\
\hline $\begin{array}{l}\text { LABA BERSIH } \\
\text { SETELAH PAJAK }\end{array}$ & $\mathbf{5 8 4 . 5 0 9}$ & $\mathbf{5 8 4 . 2 0 0}$ & $\mathbf{5 3 9 . 2 4 4}$ \\
\hline
\end{tabular}

Sumber: Laporan Keuangan Tahunan

PT. Ultra Jaya Milk Industry Tbk, 2020 (data di olah)

Tabel 3. Neraca PT. Ultra Jaya Milk Industry Tbk Tahun 2017-2019

\begin{tabular}{|c|c|c|c|}
\hline \multirow[b]{2}{*}{ Keterangan } & \multicolumn{3}{|c|}{ Tahun } \\
\hline & $\begin{array}{l}\begin{array}{c}2017 \\
\text { (dalam }\end{array} \\
\text { jutaan } \\
\text { rupiah) }\end{array}$ & $\begin{array}{c}2018 \\
\text { (dalam } \\
\text { jutaan } \\
\text { rupiah) }\end{array}$ & $\begin{array}{c}2019 \\
\text { (dalam } \\
\text { jutaan } \\
\text { rupiah) }\end{array}$ \\
\hline \multicolumn{4}{|l|}{ Aset } \\
\hline \multicolumn{4}{|l|}{ Aset Lancar } \\
\hline $\begin{array}{l}\text { Kas dan setara } \\
\text { kas }\end{array}$ & 2.120 .400 & 1.444 .310 & 2.040 .591 \\
\hline \multicolumn{4}{|l|}{ Piutang usaha } \\
\hline $\begin{array}{c}\text { Pihak } \\
\text { berelasi }\end{array}$ & 17.900 & 4.128 & 3.876 \\
\hline Pihak ketiga & 16.658 & 27.156 & 36.109 \\
\hline $\begin{array}{l}\text { Piutang lain- } \\
\text { lain-pihak } \\
\text { ketiga }\end{array}$ & 33.395 & 30.121 & 38.822 \\
\hline Persediaan & 682.624 & 708.773 & 987.927 \\
\hline $\begin{array}{l}\text { Uang muka } \\
\text { pembelian }\end{array}$ & 76.785 & 60.942 & 10.864 \\
\hline $\begin{array}{l}\text { Pajak di bayar } \\
\text { di muka }\end{array}$ & 16.559 & 11.072 & 16.441 \\
\hline $\begin{array}{l}\text { Biaya di bayar } \\
\text { di muka }\end{array}$ & 5.598 & 7.805 & 8.751 \\
\hline $\begin{array}{l}\text { Jumlah Aset } \\
\text { Lancar }\end{array}$ & 3.439 .990 & 2.793 .521 & 3.716 .641 \\
\hline \multicolumn{4}{|l|}{$\begin{array}{l}\text { Asset Tidak } \\
\text { Lancar }\end{array}$} \\
\hline $\begin{array}{l}\text { Asset Pajak } \\
\text { Tangguhan }\end{array}$ & 27.177 & 17.331 & 15.183 \\
\hline $\begin{array}{l}\text { Asset tetap } \\
\text { setelah } \\
\text { dikurangi } \\
\text { akumuluasi } \\
\text { penyusutan }\end{array}$ & 1.336 .398 & 1.453 .135 & 1.556 .666 \\
\hline $\begin{array}{l}\text { Uang muka } \\
\text { pembelian } \\
\text { asset tetap }\end{array}$ & 207.045 & 340.758 & 334.139 \\
\hline
\end{tabular}

\begin{tabular}{|c|c|c|c|}
\hline Uang jaminan & 9.455 & 23.551 & 1.764 \\
\hline $\begin{array}{l}\text { Aset tidak } \\
\text { lancar lainnya }\end{array}$ & 216.500 & 364.309 & 335.903 \\
\hline $\begin{array}{l}\text { Jumlah Aset } \\
\text { Tidak Lancar }\end{array}$ & 1.735 .906 & 2.762 .350 & 2.891 .781 \\
\hline Jumlah Aset & 5.175 .896 & 5.555.871 & 6.608.422 \\
\hline \multicolumn{4}{|l|}{$\begin{array}{l}\text { Liabilitas dan } \\
\text { Ekuitas }\end{array}$} \\
\hline \multicolumn{4}{|l|}{ Liabilitas } \\
\hline $\begin{array}{l}\text { Liabilitas } \\
\text { jangka pendek }\end{array}$ & 820.625 & 635.161 & 836.314 \\
\hline $\begin{array}{l}\text { Liabilitas } \\
\text { jangka panjang }\end{array}$ & 157.560 & 145.754 & 116.969 \\
\hline $\begin{array}{l}\text { Jumlah } \\
\text { Liabilitas }\end{array}$ & 978.185 & 780.915 & 953.283 \\
\hline \multicolumn{4}{|l|}{ Ekuitas } \\
\hline Modal saham & 577.676 & 577.676 & 577.676 \\
\hline $\begin{array}{l}\text { Tambahan } \\
\text { modal di setor }\end{array}$ & 51.251 & 51.251 & 51.251 \\
\hline \multicolumn{4}{|l|}{ Saldo laba } \\
\hline $\begin{array}{l}\text { Ditentukan } \\
\text { penggunaannya }\end{array}$ & 135.100 & 135.100 & 135.100 \\
\hline $\begin{array}{l}\text { Belum } \\
\text { ditentukan } \\
\text { penggunaannya }\end{array}$ & 3.331 .761 & 3.914 .010 & 4.807 .645 \\
\hline $\begin{array}{l}\text { Selisih kurs } \\
\text { penjabaran }\end{array}$ & -13.886 & -25.851 & -38.358 \\
\hline Jumlah & 3.317 .875 & 3.888 .159 & 4.769 .287 \\
\hline $\begin{array}{l}\text { Kepentingan } \\
\text { non pengendali }\end{array}$ & 121.118 & 114.684 & 106.700 \\
\hline $\begin{array}{l}\text { Jumlah } \\
\text { Ekuitas }\end{array}$ & 4.197 .711 & 4.774 .956 & 5.655 .139 \\
\hline $\begin{array}{l}\text { Jumlah } \\
\text { Liabilitas dan } \\
\text { Ekuitas }\end{array}$ & 5.175 .896 & 5.555 .871 & 6.608 .422 \\
\hline
\end{tabular}

Sumber: Laporan Keuangan Tahunan PT. Ultra Jaya Milk Industry Tbk, 2020 (data di olah)

\section{B. Tahapan Perhitungan Economic Value Added (EVA) PT. Ultra Jaya Milk Industry Tbk Tahun 2017-2019}

Sebelum melakukan perhitungan Economic Value Added (EVA), ada beberapa tahapan yang harus di hitung yaitu sebagai berikut:

1) Perhitungan NOPAT

Tabel 4. Besarnya Tingkat Laba (NOPAT) PT. Ultra Jaya Milk Industry Tbk

(dalam Jutaan Rupiah)

\begin{tabular}{|c|c|c|c|}
\hline Tahun & $\begin{array}{c}\text { Laba } \\
\text { Sebelum } \\
\text { Bunga } \\
\text { dan } \\
\text { Pajak } \\
\text { (1) }\end{array}$ & $\begin{array}{c}\text { Pajak } \\
\text { (2) }\end{array}$ & $\begin{array}{l}\text { NOPAT } \\
\qquad(1-2)\end{array}$ \\
\hline 2017 & 870.375 & 285.866 & 584.509 \\
\hline
\end{tabular}


PAY Jurnal Keuangan dan Perbankan. Vol. 2 No. 2, Desember 2020

\begin{tabular}{|l|l|l|l|}
\hline 2018 & 801.539 & 217.339 & 584.200 \\
\hline 2019 & 846.252 & 307.088 & 539.164 \\
\hline
\end{tabular}

Sumber: Laporan Keuangan Tahunan PT. Ultra Jaya Milk Industry Tbk, 2020 (data di olah)

2) Perhitungan Invested Capital

Tabel 5. Invested Capital PT. Ultra Jaya Milk Industry Tbk

(dalam Jutaan Rupiah)

\begin{tabular}{|c|c|c|c|}
\hline Tahun & $\begin{array}{c}\text { Total } \\
\text { Hutang } \\
\text { dan } \\
\text { Ekuitas }\end{array}$ & $\begin{array}{c}\text { Hutang } \\
\text { Jangka } \\
\text { Pendek }\end{array}$ & $\begin{array}{c}\text { Invested } \\
\text { Capital }\end{array}$ \\
\hline 2017 & 5.175 .896 & 820.625 & 4.355 .271 \\
\hline 2018 & 5.555 .871 & 635.161 & 4.920 .710 \\
\hline 2019 & 6.608 .422 & 836.314 & 5.772 .108 \\
\hline
\end{tabular}

Sumber: Laporan Keuangan Tahunan PT. Ultra Jaya Milk Industry Tbk, 2020 (data di olah)

3) Perhitungan Biaya Modal Rata-Rata Tertimbang (WACC)

a. Tingkat Modal (D)

Tabel 6. Tingkat Modal PT. Ultra Jaya Milk Industry Tbk

\begin{tabular}{|c|c|c|c|c|}
\hline Tahun & $\begin{array}{c}\text { Total } \\
\text { Hutang } \\
\text { (dlm } \\
\text { jutaan } \\
\text { rupiah) }\end{array}$ & $\begin{array}{c}\text { Total } \\
\text { Hutang } \\
\text { dan } \\
\text { Ekuitas } \\
\text { (dlm jutaan } \\
\text { rupiah) }\end{array}$ & Persentase & $\begin{array}{c}\text { Tingkat } \\
\text { Modal } \\
\text { (D) }\end{array}$ \\
\hline 2017 & 978.185 & 5.175 .896 & $100 \%$ & $18,89 \%$ \\
\hline 2018 & 780.915 & 5.555 .871 & $100 \%$ & $14,05 \%$ \\
\hline 2019 & 953.283 & 6.608 .422 & $100 \%$ & $14,42 \%$ \\
\hline
\end{tabular}

Sumber: Laporan Keuangan Tahunan PT. Ultra Jaya Milk Industry Tbk, 2020 (data di olah)

\section{b. Cost of Debt (rd)}

Tabel 7. Cost of Debt PT. Ultra Jaya Milk Industry Tbk

\begin{tabular}{|c|c|c|c|c|}
\hline Tahun & $\begin{array}{c}\text { Beban } \\
\text { Bunga } \\
(\mathrm{dlm} \\
\text { jutaan } \\
\text { rupiah) }\end{array}$ & $\begin{array}{c}\text { Total } \\
\text { Hutang } \\
(\mathrm{dlm} \\
\text { jutaan } \\
\text { rupiah) }\end{array}$ & Persentase & $\begin{array}{c}\text { Cost } \\
\text { of } \\
\text { Debt } \\
\text { (rd) }\end{array}$ \\
\hline 2017 & 1.500 & 978.185 & $100 \%$ & $0,15 \%$ \\
\hline 2018 & 1.247 & 780.915 & $100 \%$ & $0,15 \%$ \\
\hline 2019 & 1.463 & 953.283 & $100 \%$ & $0,15 \%$ \\
\hline
\end{tabular}

Sumber: Laporan Keuangan Tahunan PT. Ultra Jaya Milk Industry Tbk, 2020 (data di olah) c. Tingkat Modal dan Ekuitas (E)

Tabel 8. Tingkat Modal dan Ekuitas PT. Ultra Jaya Milk Industry Tbk

\begin{tabular}{|c|c|c|c|c|}
\hline Tahun & $\begin{array}{c}\text { Total } \\
\text { Ekuitas } \\
\text { (dlm } \\
\text { jutaan } \\
\text { rupiah) }\end{array}$ & $\begin{array}{c}\text { Total } \\
\text { Hutang } \\
\text { dan } \\
\text { Ekuitas } \\
\text { (dlm } \\
\text { jutan } \\
\text { rupiah) }\end{array}$ & Persentase & $\begin{array}{c}\text { Tingkat } \\
\text { Modal } \\
\text { dan } \\
\text { Ekuitas } \\
\text { (E) }\end{array}$ \\
\hline 2017 & 4.197 .711 & 5.175 .896 & $100 \%$ & $81,10 \%$ \\
\hline 2018 & 4.774 .956 & 5.555 .871 & $100 \%$ & $85,94 \%$ \\
\hline 2019 & 5.655 .139 & 6.608 .422 & $100 \%$ & $85,57 \%$ \\
\hline
\end{tabular}

Sumber: Laporan Keuangan Tahunan PT. Ultra Jaya Milk Industry Tbk, 2020 (data di olah)

\section{d. Cost of Equity (re)}

Tabel 9. Cost of Equity PT. Ultra Jaya Milk Industry Tbk

\begin{tabular}{|c|c|c|c|c|}
\hline \multirow{7}{*}{ Tahun } & $\begin{array}{c}\text { Laba } \\
\text { Bersih } \\
\text { Setelah } \\
\text { Pajak } \\
\text { (dlm } \\
\text { jutaan } \\
\text { rupiah) }\end{array}$ & $\begin{array}{c}\text { Total } \\
\text { Ekuitas } \\
\text { (dlm jutaan } \\
\text { rupiah) }\end{array}$ & $\begin{array}{c}\text { Persen } \\
\text { tase }\end{array}$ & $\begin{array}{c}\text { Cost of } \\
\text { Equity } \\
\text { (re) }\end{array}$ \\
\hline 2017 & 584.509 & 4.197 .711 & $100 \%$ & $13,92 \%$ \\
\hline 2018 & 584.200 & 4.774 .956 & $100 \%$ & $12,23 \%$ \\
\hline 2019 & 539.244 & 5.655 .139 & $100 \%$ & $9,53 \%$ \\
\hline
\end{tabular}

Sumber: Laporan Keuangan Tahunan PT. Ultra Jaya Milk Industry Tbk, 2020 (data di olah)

e. Tingkat Pajak (Tax)

Tabel 10. Tingkat Pajak PT. Ultra Jaya Milk Industry Tbk

\begin{tabular}{|c|c|c|c|c|}
\hline Tahun & $\begin{array}{c}\text { Beban } \\
\text { Pajak } \\
\text { (dlm } \\
\text { jutaan } \\
\text { rupiah) }\end{array}$ & $\begin{array}{c}\text { Laba } \\
\text { Bersih } \\
\text { Sebelum } \\
\text { Pajak } \\
\text { (dlm } \\
\text { jutaan } \\
\text { rupiah) }\end{array}$ & Persentase & $\begin{array}{c}\text { Tingkat } \\
\text { Pajak } \\
\text { (Tax) }\end{array}$ \\
\hline 2017 & 285.866 & 870.375 & $100 \%$ & $32,84 \%$ \\
\hline 2018 & 217.339 & 801.539 & $100 \%$ & $27,11 \%$ \\
\hline 2019 & 307.008 & 846.252 & $100 \%$ & $36,27 \%$ \\
\hline
\end{tabular}

Sumber: Laporan Keuangan Tahunan PT. Ultra Jaya Milk Industry Tbk, 2020 (data di olah)

Berdasarkan tahapan di atas, maka dapat dihitung WACC PT. Ultra Jaya Milk Industry Tbk Tahun 2017-2019, sebagai berikut:

$$
\begin{gathered}
\text { WACC }_{2017}=\{(\mathrm{D} \times \mathrm{rd})(1-\mathrm{Tax})+(\mathrm{E} \times \mathrm{re})\} \\
=\{0,1889 \times 0,0015)(1-0,3284)+ \\
(0,8110 \times 0,1392)\}
\end{gathered}
$$




$$
\begin{aligned}
& =0,11 \\
\text { WACC }_{2018} & =\{(\mathrm{D} \times \mathrm{rd})(1-\mathrm{Tax})+(\mathrm{E} \times \mathrm{re})\} \\
& =\{(0,1405 \times 0,0015)(1-0,2711) \\
& +(0,8594 \times 0,1223)\} \\
& =0,10 \\
\text { WACC }_{2019} & =\{(\mathrm{D} \times \mathrm{rd})(1-\mathrm{Tax})+(\mathrm{E} \times \mathrm{re})\} \\
& =\{(0,1442 \times 0,0015)(1-0,3627) \\
& +(0,8557 \times 0,0953)\} \\
& =0,08
\end{aligned}
$$

Tabel 11. Rekapitulasi Perhitungan WACC PT. Ultra Jaya Milk Industry Tbk Tahun 2017-2019

\begin{tabular}{|c|c|}
\hline Tahun & WACC \\
\hline 2017 & 0,11 \\
\hline 2018 & 0,10 \\
\hline 2019 & 0,08 \\
\hline
\end{tabular}

f. Perhitungan Capital Charges

Tabel 12. Capital Charges PT. Ultra Jaya Milk Industry Tbk

\begin{tabular}{|c|c|c|c|}
\hline Tahun & $\begin{array}{c}\text { WACC } \\
(\mathbf{1})\end{array}$ & $\begin{array}{c}\text { Invested } \\
\text { Capital } \\
(\mathbf{2})\end{array}$ & $\begin{array}{c}\text { Capital } \\
\text { Charges } \\
(\mathbf{1 x 2})\end{array}$ \\
\hline 2017 & 0,11 & 4.355 .271 & $479.079,81$ \\
\hline 2018 & 0,10 & 4.920 .710 & 492.071 \\
\hline 2019 & 0,08 & 5.772 .108 & $461.768,64$ \\
\hline
\end{tabular}

Sumber: PT. Ultra Jaya Milk Industri Tbk, 2020 (data di olah)

g. Perhitungan Economic Value Added (EVA)

EVA $=$ NOPAT - Capital Charges

Tabel 13. Economic Value Added (EVA) PT. Ultra Jaya Milk Industry

\begin{tabular}{|c|c|c|c|c|c|}
\multicolumn{7}{|c|}{ Tbk } \\
Tahun & $\begin{array}{c}\text { NOPAT } \\
\text { (dlm } \\
\text { jutaan } \\
\text { rupiah) }\end{array}$ & $\begin{array}{c}\text { Capital } \\
\text { Charges } \\
\text { (dlm jutaan } \\
\text { rupiah) }\end{array}$ & $\begin{array}{c}\text { EVA } \\
\text { (dlm jutaan } \\
\text { rupiah) }\end{array}$ & Kriteria & $\begin{array}{c}\text { Kinerj } \\
\text { a }\end{array}$ \\
\hline 2017 & 584.509 & $479.079,81$ & $105.429,19$ & EVA>0 & Baik \\
\hline 2018 & 584.200 & 492.071 & 92.129 & EVA>0 & Baik \\
\hline 2019 & 539.164 & $461.768,64$ & $77.395,36$ & EVA $>0$ & Baik \\
\hline
\end{tabular}

Sumber: PT. Ultra Jaya Milk Industri Tbk, 2020 (data di olah)

Berdasarkan hasil perhitungan Economic Value Added (EVA) PT. Ultra Jaya Milk Industry Tbk Tahun 2017 sampai dengan tahun 2019, menunjukkan bahwa pengukuran kinerja keuangan dengan metode Economic
Value Added (EVA) untuk tahun 2017 sebesar Rp105.429.000.000 kemudian mengalami penurunan pada tahun 2018 sebesar Rp 92.129.000.000, selanjutnya pada tahun 2019 kembali mengalami penurunan sebesar Rp 77.395.000.000. Sesuai dengan kriteria Economic Value Added (EVA) dari tahun 2017 sampai tahun 2019 nilai EVA > 0, artinya kinerja keuangan PT. Ultra Jaya Milk Industry Tbk dalam keadaan baik atau terjadi NITAMI (Nilai Tambah Ekonomi). Hal ini di sebabkan laba usaha yang dihasilkan pada tahun 2017 sampai 2019 oleh perusahaan cukup tinggi, sehingga dapat di bandingkan antara nilai capital charges dengan nilai NOPAT, bahwa nilai NOPAT lebih besar di bandingkan dengan nilai capital charges dan dari komponen masing-masing biaya modal (WACC) yang kecil sehingga dari nilai NOPAT tersebut perusahaan dapat menghasilkan nilai yang dapat menutup kewajiban kepada para pemegang saham.

Selain itu hasil Economic Value Added (EVA) yang diperoleh dari tahun 2017 hingga tahun 2019 bernilai positif yang dimana jika EVA>0 menandakan bahwa perusahaan mampu menciptakan nilai tambah ekonomis dengan menghasilkan tingkat pengembalian yang melebihi biaya modalnya. Sehingga dengan adanya kemampuan perusahaan dalam menciptakan nilai tambah tersebut membuktikan bahwa kinerja keuangan perusahaan dalam keadaan baik.

\section{KESIMPULAN}

Berdasarkan hasil analisis dan pembahasan di atas, maka dapat ditarik kesimpulan darikeseluruhan hasil analisis yaitu pengukuran kinerja keuangan dengan menggunakan metode Economic Value Added (EVA) menunjukkan bahwa kinerja keuangan PT. Ultra Jaya Milk Industry Tbk pada 


\section{PAY Jurnal Keuangan dan Perbankan. Vol. 2 No. 2, Desember 2020}

tahun 2017-2019 dalam keadaan baik karena Economic Value Added (EVA) bernilai positif dimana nilai EVA $>0$ sehingga dapat dikatakan bahwa terjadi proses nilai tambah ekonomis bagi perusahaan, karena laba yang tersedia bias memenuhi harapan stakeholder terutama Investor..

\section{SARAN}

Dari kesimpulan tersebut, maka selanjutnya saran yang dapat diberikan bagi pihak perusahaan adalah untuk selalu mengevaluasi pengukuran kinerja keuangan, hal ini dilakukan agar perusahaan dapat menilai kinerja keuangan perusahaan dengan tepat. Bagi para investor dan calon investor agar dapat mempertimbangkan dengan lebih cermat dalam pengambilan keputusan investasi, selain menggunakan analisis kinerja keuangan investor juga perlu memperhatikan kondisi eksternalnya, sehingga investor dapat melihat prospek dan kelanjutan bisnis di masa depan.

\section{DAFTAR PUSTAKA}

Endang. 2016. Pengukuran Kinerja Keuangan PT. Mayora Indah Tbk dengan Pendekatan Economic Value Added. Jurnal ACSY Volume IV No. 1, April.

Hanafi, Mamduh dan Halim, Abdul. 2012. Analisis Laporan Keuangan. Edisi ketiga. Cetakan Pertama. Penerbit UUP-AMP, Yogyakarta.

Harahap, Sofyan Syafri. 2013. Analisis Kritis Atas Laporan Keuangan. Cetakan kesebelas, Penerbit Rajawali Pers, Jakarta.

Ikatan Akuntansi Indonesia. 2009. standar akuntansi keuangan, penerbit PT. Salemba Empat, Jakarta.

Kasmir. 2017. Analisis Laporan Keuangan, Cetakan Kesepuluh,
Jakarta: PT. RajaGrafindo Persada.

Munawir, S.2014. Analisis Laporan Keuangan Teori dan Aplikasi, Edisi Keempat, Cetakan kedelapan, (Yogyakarta:, Liberty).

Mursidin, 2018. Analisis Kinerja Keuangan Dengan Metode EVA Pada Perusahaan Marmer Yang Terdaftar Di Bursa Efek Indonesia (BEI) Dalam Studi Kasus PT. Citatah Tbk. Maros: Universitas Muslim Maros.

Nur, Sri Wahyuni., Ulfa Hidayati dan Nurfitriani, 2019. Analisis Perputaran Piutang untuk Menilai Kinerja Keuangan PT. Prima Karya Manungal Kabupaten Pangkep. PAY Jurnal Keuangan dan Perbankan, Vol. 2 No. $\quad 1$, 42-51. https://ejournals.umma.ac.id/ind ex.php/pay/article/view/591.

Rany Feranita, 2017. Analisis Kinerja Keuangan Dengan Menggunakan Metode EVA (Studi Kasus Pada Perusahan Sektor Pertanian Yang Terdaftar di ISSI). Palembang: UIN Raden Fatah Palembang.

Tunggal, Amin Wijaya. 2008. Akuntansi Manajemen, Economic Value Added (EVA) Economic Value Added (EVA). Jakarta. PT. Rineka Cipta.

Young, S. David. 2005. EVA dan Manajemen Berdasarkan Nilai. Edisi Kedua. Jakarta. Salemba Empat.

Yuwono, Sony, dkk. 2005. Petunjuk Praktis Penyusunan Balance Score Card. Cetakan Kedua. Jakarta. Gramedia. 